

\title{
Fixed lingual retainer positioner: A narative review
}

\author{
Medha Lakhanam ${ }^{1}$; Kamna Srivastava ${ }^{2}$; Raghavendr Singh ${ }^{3}$ \\ ${ }^{1}$ Department of Orthodontics and Dentofacial Orthopaedics, Gorakhpur (U.P) \\ ${ }^{2}$ Department of Orthodontics and Denofacial Orthopaedics, Babu banarasi das college of dental sciences, Lucknow (U.P) \\ ${ }^{3}$ Department of Pediatric and Preventive Dentistry, Purvanchal Institute of Dental Sciences, Gorakhpur (U.P)
}

\begin{abstract}
Introduction: Retention is one of the most crucial phase of the any orthodontic treatment to maintain the desired result obtained. Therefore, the applying of an appropriate retention method is very important both for prevention of relapse after treatment and for increasing patient satisfaction. Aim: This research paper aims to evaluate the effectiveness of different methods of fixed retention based on the data available that outlines an evidence-based choice of the retention procedure for different cases.

Material and method: A search in electronic databases (PubMed, Cochrane Library, Science Direct, Embase, ProQuest, Ebsco, Biomed Central, Medline, Lilacs, and Google Scholar) and a manual search with no language restrictions. The inclusion criteria were: randomized clinical trials and meta-analysis, prospective and retrospective studies, studies in humans, clinical and radiographical studies evaluating the periodontium, studies of different retention techniques performed during the 1995-2019 period.

Conclusion: This research paper concludes that adequate stabilization of lingual retainer wire prior to bonding can reduce chair side time in its placement, thereby reducing the chances of contamination and bond failure. Depending on clinicians convenience and ease of adapting a technique, any of these methods can be used to stabilize lingual retainer for effective retention of post treatment result.
\end{abstract}

Lakham M, Srivastava K, Singh R. Fixed lingual retainer positioner: A narrative review South Eur J Orthod Dentofac Res. 2020;7(S1):2-5.

\section{INTRODUCTION}

Angle stated that "the problem involved in retention are greater than the difficulties being encountered in the treatment, and tests the utmost skill of the operator. ${ }^{1}$ Retention is one of the most critical phase of Orthodontic treatment that involves use of both removable and fixed retainers. The various retention appliances available include Removable retainers and bonded retainers. Removable retainers have their own advantages and disadvantages, but they need patient's compliance to wear them. Fixed retainers consist of a length of orthodontic wire that is bonded on the lingual aspect of tooth. ${ }^{2}$ The major advantages of

\author{
Corresponding Author: \\ Medha Lakhanam \\ Department of Orthodontics and Dentofacial Orthopaedics, \\ Gorakhpur (U.P), \\ India. \\ e-mail: medhalakhanam@gmail.com
}

fixed retainers includes invisibility, minimal patient compliance and provides long term retention.

Though fixed retainers are advantageous, however their placement requires longer working time, has a risk of contamination from saliva and moisture ${ }^{3}$, difficulty in adaptation of the retainer wire to lingual surface of anterior teeth ${ }^{2}$, hence their stabilization during bonding is a difficult task. If retainer wire can be effectively stabilized over the lingual surface of tooth prior to bonding, bonding becomes a simple process. For this, use of separators (Kesling and elastomeric separators), materials like resin, memosil, glue etc or use of metal Stablizers in form of W, V or use of wires had been used by various author to stabilized fixed retainers.

Bonding of a lingual retainer is a challenging and technique sensitive procedure hence various methods used to stabilize lingual retainer before bonding ${ }^{4}$. The objectives of this article is to compile the different retention techniques used to stabilize the lingual retainer wire for bonding altogether at one place. 


\section{MATERIALS AND METHODS}

A search in electronic databases (PubMed, Cochrane Library, Science Direct, Embase, ProQuest, Ebsco, Biomed Central, Medline, Lilacs, and Google Scholar) and a manual search with no language restrictions. The inclusion criteria were: randomized clinical trials and meta-analysis, prospective and retrospective studies, studies in humans, clinical and radiographical studies evaluating the periodontium, studies of different retention techniques performed during the 1995-2019 period. Here in this article we had chosen the various methods that were easily fabricated, less armamentarium requisite and less time consuming for operator.

\section{Summary of the stabilization methods}

\section{Stablization of lingual retainer by separator}

\section{i. Using Modified Kesling's separator}

The conventional Kesling's separator made by 0.014 ' AJ wilcock wire and used for slow seperation in area offering tight contact, was modified by Nagar et al..$^{5}$ by incorporating a perpendicular bend in lower arm to form a ' $U$ '. The $U$ would exert pressure on lingual retainer wire against palatal tooth surface. These were removed after bonding the lingual retainer.

ii. Stablizing lingual retainer wire using Modified Kesling's separator

a. Sahu S. et al. developed retainer positioner that looked like a modified Kesling separator and was made of $0.016^{\prime \prime}$ Australian AJ. Wilocock special plus wire. ${ }^{6}$ The smaller leg was shorter by $2 \mathrm{~mm}$ and positioned labially. The longer leg had offsets which use to keep the positioner away from the lingual mucosa. The incisal offset helds the retainer wire in position. ${ }^{6}$

b. Karthikeyan M.K. et al. developed a Stabilising Spring which is also a modification of kesling seprators is easy

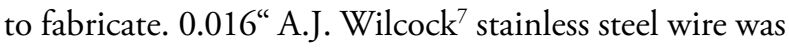
used for the fabrication. In Kesling separator, instead of straight leg, right angle bend was given to the leg overlapping the helix. ${ }^{7}$ Then, the wire was bent to form a U-shaped configuration on both the legs, for holding the retainer on the lingual side and on the labial side of the tooth for stabilisation. The length of the spring was determined, based on the clinical crown length extended up to the gingival margin and fixed in the interdental region. ${ }^{7}$ The spring should be firm, but not too tight that it injures the gingiva.

\section{iii. Using elastomeric separators}

Thamer Adel Alkhadra et al. ${ }^{8}$ developed a technique in which lingual retainers wire was passed through the elastomeric separators to stabilize the lingual retainer wire that were placed interdentally between alternate tooth contacts.

\section{Stablization of lingual retainer by other materials}

\section{i. Using DuraLay resin transfer}

Shin-Jae Lee et al. ${ }^{9}$ in 2004 proposed this method of stablising lingual retainer. Before debonding, an impression was taken and poured in hard stone. ${ }^{9}$ Lingual retainer wire was adapted on to lingual surface to accurately fit the cast. After application of DuraLay separating medium to the cast, the DuraLay resin is mixed and appllied gently between the distal surface of the second premolar and the mesial surface of the first molar. ${ }^{9}$ Duralay resin will act as a template / resin guide to place the lingual retainer in patient's mouth and this is fixed with utility wax. After completing the bonding in anterior segment, terminal portions of wires were cut, resin guide was removed and terminal wires were bonded.

\section{ii. Using Kommon Base Resin}

Yoshida Y. et al. ${ }^{10}$ introduced a retainer that was adapted with bonding pads made up of Kommon base at the canines. A small amount of Kommon Base Resin was applied to each bonding pad, and cured. Gently remove the appliance from the working cast with a tweezer. Apply a resin-reinforced glass ionomer cement to the interior surfaces of the Kommon bases and retainers was fixed lingually.

\section{iii. Using modeling wax}

Hattarki R. et al. ${ }^{11}$ described a new method for placement of lingual retainers. For a 3 - 3 retainer, wire was extended to the first premolars. A small sheet of modeling wax was taken and adapted from premolar to premolar, covering the labial and lingual surfaces of the teeth. Wax was removed at the areas corresponding to the centre of each tooth. This transfer tray was used to bond lingual retainer at the trenches cut in the wax.

\section{iv. Using Memosil}

Similar to Duralay resin transfer method, O.P. Kharbanda proposed a method using Memosil. ${ }^{12}$ Retainer was adapted and fixed on the mesial pit of second premolar using memosil. Tooth pick was cut equal to the interpremolar width at mesial pits of second premolar and placed before memosil sets. ${ }^{12}$ This will act like a template to stabilize retainer. After bonding anterior teeth, this assembly was removed and terminal ends were bonded.

v. Using Hot Glue

As proposed by Sahu S.K. et al. ${ }^{13}$ template could also be made by hot glue that was fixed on canine and premolar 
region using glue gun. The glue positioner is then used in patients's mouth to stabilize lingual retainer.

\section{vi. Using PVS Transfer Tray Technique}

Bhardwaj M. et al. ${ }^{14}$ used PVS impression material for making transfer tray to bond lingual retainer. PVS impression material was added after mixing on the labial surface of anterior teeth which covers all the incisal edges for proper guidance while placing the tray in patients mouth. ${ }^{14}$ On the lingual surface the retainer wire was adapted and secured by vertical arms made from putty. This assembly was placed on patient's mouth after removing from working model. ${ }^{14}$

\section{By use of metal stabilizers}

\section{i. Ligature Wire Technique}

Vibhute PJ. et al. ${ }^{15}$ introduced two new different techniques for bonding fixed retainer direct and indirect. In the first technique, lingual retainer wire was stabilized using ligature wire tied to $0.8-0.9 \mathrm{~mm}$ hard round SS wire with helices distal to canine at both ends. In the second technique retainer wire was stabilized by individual ligature wire passed through interdental areas.

\section{ii. Using molar bands}

Seth V. et al. ${ }^{16}$ developed this technique of bonding lingual retainer.The alginate impression was made after reseating the molar bands loosly without cementation. The retainer was secured on the working cast with Super Glue (quickfix) and on the molar bands the terminal ends were soldered. ${ }^{17}$ The molar bands alongwith retainer are placed in the patient's mouth by removing carefully from the cast. ${ }^{17}$

\section{iii. W Shaped Lingual Reatiner Wire Stabliser}

Garabadu A. et al. ${ }^{18}$ constructed a device by soldering two equal pieces of $10 \mathrm{~mm}$ of 19 gauge S.S Wire to straight probe at an angle of $45^{\circ}$ to each other. These arms hold the wire on lingual surface of upper and lower incisors. ${ }^{18}$ The middle arm was the guiding arm that was placed between the central incisor and other two arms were used left and right arm to hold the wire interdentally between lateral incisor and canine of the both sides. ${ }^{18}$ This device was easily fabricated, saves the time and adapt the wire perfectly on the lingual surface.

\section{iv. Rest Appliance}

Bansal A. ${ }^{19}$ developed the Rest stabilizer, with $0.7 \mathrm{~mm}$ round SS wire on working model. The wire was bend in V shape with helices away from tissue surface on lingual side. Labial wire assembly was prepared with $0.9 \mathrm{~mm}$ round SS wire and V shaped wire components were soldered. This was termed as the "rest appliance" to hold retainer wire. ${ }^{19}$ v. Using " $V$ " clips

Chaudhari CV. et al. ${ }^{20}$ used 0.018” AJ Wilcock stainless steel (SS) wire and place it the labial aspect of the tooth. The wire was extended to the incisal area and bend lingually. Markings were done at the area where the fixed lingual retainer was to be given, and round bend was given facing to the lingual embrasure area. After drying from, there was applicaton of the bonding agent. The retainer wire was stabilized with "V" retainer clip on the lingual surface. ${ }^{21}$ In general, upper and lower arch requires 4 and 3 clips, respectively. After stabilization, the composite was applied and cured on the lingual surface over the retainer wire.

\section{vi. Lingual Retainer Stabilizer (LIAR)}

Srivastava A. et al. ${ }^{22}$ fabricated a spring using 24 gauge stainless steel wire to stabilize the lingual retainer. There was fabrication of two concentric helices of $2-3 \mathrm{~mm}$ internal diameter followed by the other end being bent into another helix perpendicular to the first loop. The second arm or palatal arm was gradually curved to adapt well on to the lingual/palatal surface of the anterior teeth. ${ }^{22}$ A used module strip with equidistant 5-6 holes was taken. The ' $U$ ' loop end was engaged in to holes of module and second stabilizer through another hole at the other end. The stabilizers can be engaged through the sequence of holes on the module strip as per requirement during bonding. 22

\section{Placing the fixed retainer prior to debonding}

\section{i. Using modifying archwire}

Astekar S. et al. ${ }^{23}$ modified the arch wire prior to debonding to stabilize the lingual fixed retainer. In the interdental area between lateral incisor and canine a $90^{\circ}$ bend was given in $0.019^{\prime} \times 0.025^{\prime}$ 'stainless steel wire or the last stainless wire (round or rectangular of at least 0.014 ') used in patient. ${ }^{23}$ Another bend of 7 to $8 \mathrm{~mm}$ length vertical arm was placed and the construction of the wire was completed by bending the retentive tags in the archwire, which extends lingually. ${ }^{23}$ The retainer wire was bend as necessary and secured, the retentive tags were kept away from the bonding areas. The bonding procedure was completed as usual. ${ }^{23}$

\section{ii. Retainer clip stabilizer for lingual retainer}

Handral R.K. et al invented a retainer clip stabilizer to stabilize the retention wire. ${ }^{1}$ The clip was fabricated by $0.017^{\prime \prime} \times 0.025^{\prime \prime}$ TMA wire. To adjuat the wire on the labiopalatal thickness of the tooth a helix was (Bend-A). ${ }^{1}$ Two arms were fabricated in which shorter one was on palatal surface and longer one was on labial surface. For adaptation on the the palatal surface, the wire was contoured according tio surface (Bend-B). The labial part 
or the longer part was given at right angle for engaging the clip into the slot of the bracket (Bend-C) ${ }^{1}$. To prevent from slippage from the slot one more horizontal bend was given at the labial part of the wire (Bend-D). ${ }^{1}$

\section{CONCLUSION}

Adequate stabilization of lingual retainer wire prior to bonding can reduce chair side time in its placement, thereby reducing the chances of contamination and bond failure. Depending on clinicians convenience and ease of adapting a technique, any of these methods can be used to stabilize lingual retainer for effective retention of post treatment result. In general, patients finds permanent bonded retainers more favorable due to its effectiveness, comfort, and aesthetics. ${ }^{3}$

\section{CONFLICT OF INTEREST}

The authors of the present article declare no conflicts of interest.

\section{REFERENCES}

1. Handral RK, Gogineni R, Mendigeri V. Retainer clip - stabilizer for lingual retainer. J Indian Orthod Soc. 2017;51:134-5.

2. Bearn D.R. Bonded Orthodontic Retainers: A review. Am J Orthod Dentofac Orthop.1995;108:207-13.

3. Eapen JC, Prakash A. Enigma of Fixed Retainers. Orthod J Nepal. 2017:52-5.

4. Ardeshna PA. Fixed Retention In Orthodontics. Decisions in Dentistry. 2019;5(10):16-18,21-22.

5. Nagar N . Modified Kesling's Separators For Stabilizing Lingual Retainer Wire. Annals of Dental Research. 2011;1(1): 96-99.

6. Sahu SK, Jayam BK, Barik AK. Retainer Positioner. J Ind Orthod Soc. 2012;46(1): 53-4.

7. Karthikeyan MK, Prabhakar R, Saravanan R, Rajvikram N, Kuppuchamy. Stabilizing Springs for Fixed Lingual Retainer. Journal of Clinical and Diagnostic Research. 2013; 7(11): 2647-2648.

8. Thamer Adel Alkhadra. A Simplified Technique For Chairside Bonding Of Lingual Retainer. J PDA. 2011;20 (3)

9. Lee SJ . Time-Saving Fixed Lingual Retainer Using Duralay Resin Transfer. Am J Orthod Dentofacial Orthop;125:203-5.

10. Yoshida Y, Nagashima K, Komori A. Simple and Accurate Bonding of Lingual Retainers with Kommon Base. J. Clin. Orthod. 2014; 68(5):292-4.

11. Hattarki RS, Rastogi S, A simple technique for bonding lingual retainer. Int. Journal of Orthodontics .2015;26(1):39-40.

12. Rana SS, Kharbanda OP. A robust method of bonding fixed lingual retainer. Journal of Pierre Fauchard academy.2017;31:64-66.
13. Sahu SK, Gautam N, Sahoo SN, Jagdev S. Glue retainer positioner. J Indian Orthod Soc 2017; 51:139-40.

14. Bhardwaj M, Khattri S, Kulshrestha R. Fabrication of Lingual Retainer made easy. J Clin Adv Dent. 2017;1:26-27.

15. Vibhute PJ. Two new methods for direct bonding 'lingual retainers'. J Indian Soc Pedod Prevent Dent.2009; 27(2):111-115.

16. Seth V, Kamath P, Venkatesh M .J Technique Clinic - A New Method for Bonding Lingual Retainer. Indian Journal of Dental Sciences. 2012;4(1):122-124.

17. Upadhyay M, Yadav S, Keluskar KM. Molar bands for 'precision' bonding of lingual retainers, Journal of Orthodontics, 2007; 34(1):12-15.

18. Garabadu A, Chalasani S, Vaz AC. W-Shaped Lingual Retainer Wire Stabilizer. J Ind Orthod Soc 2011;45(2):150-151.

19. Bansal A. Rest Appliance: Retainer Stabilizing Appliance. J Orthod Endod. 2017; $3: 1$

20. Chaudhari CV, Daokar SS, Yamyar SS. Simple Innovative "V" clips for bonded lingual retainer. Int J Orthod Rehabil.2018; 9:130-1.

21. Vijayalakshmi PS, Veereshi AS, Kumar M. Simplified Method of Bonding the Fixed Retainer. J Ind Orthod Soc. 2011; 45(4):260-261.

22. Srivastava A, Tikku T, Khanna R, Maurya RP, Verma SL, Srivastava K. Lingual Retainer Stabilizer (LIAR). Journal of Scientific Achievements, 2017;2(4):16-18.

23. Astekar SS, Deshpande RS, Shetty PS, Chanchad AD. Lingual Retainer Stabilized by Modifying Archwire. J Indian Orthod Soc. 2013; 47(4):483-484. 


\title{
Assessment of facial landmarks for bone asymmetry in geometric morphometric studies: A review
}

\author{
Ivana Rupić1, Ivana Čuković-Bagić ${ }^{2}$, Vladimir Ivković ${ }^{3,4}$, Tomislav Lauc ${ }^{1,5,6}$ \\ ${ }^{1}$ Apolonija Dental Clinic, Zagreb, Croatia \\ ${ }^{2}$ Department of Paediatric and Preventive Dentistry, School of Dental Medicine, University of Zagreb, Croatia \\ ${ }^{3}$ Department of Psychiatry, Massachusetts General Hospital, Charlestown, MA, United States \\ ${ }^{4}$ Department of Psychiatry, Harvard Medical School, Boston, MA, United States. \\ ${ }^{5}$ Study of Anthropology, Faculty of Social Sciences and Humanities, University of Zagreb, Croatia \\ ${ }^{6}$ School of Dental Medicine, University of Zagreb, Croatia
}

\begin{abstract}
Background: Anthropometrical points or landmarks are key for facial shape analysis using geometric morphometrics. In the early 1990s, Fred Bookstein created a classification system with landmarks type 1, type 2, type 3 based on anatomical landmark homology. However, thirty years later, a uniform directory index of landmarks that can be used for assessing facial asymmetry still does not exist. The criteria for selecting landmark points are not fully defined, making homology classification and landmarks prone to arbitrary interpretations. A literature review indicates that the authors of studies do not explain the reason for choosing exact points. Most of them also do not provide a clear definition of landmarks and landmarks classification, according to homology.

Objective: The review's objective was to assess, in an evidence-based manner, which landmarks on hard facial tissues can be recommended for facial asymmetry assessment using geometric morphometrics. This selection of landmarks can provide a better comparison to future studies and can have clinical relevance in orthodontic diagnostics.

Search methods: An electronic search of 9 databases up to March 2020 by two reviewers was conducted to identify relevant articles.

Selection criteria: Prospective randomized, non-randomized controlled trials and cross-sectional studies report facial asymmetry using three-dimensional images and geometric morphometric methods. The reasons for assessing facial asymmetry were not considered. Data collection and analysis: The 23 selected studies were categorized according to the number and specification of the research subjects, types of three-dimensional images, the number of landmarks, and the craniofacial region of interest. All landmarks were extracted with the following data: name, abbreviation, and the author's definition of the location.

Results: The craniofacial system is divided into the neurobasicranial region, ethmomaxillary region and the mandible. Assessment of neurobasicranial asymmetry was conducted in 6 studies and 45 different landmarks were recorded, of which 11 were medial and 34 bilateral. Bregma and Lambda occur most frequently and according to homology, both belong to type 1 landmarks. Assessment of ethmomaxillary asymmetry was conducted in 21 studies and 68 different landmarks were recorded, of which 16 were medial and 52 bilateral. Nasion and Jugale occur most frequently and according to homology, Nasion belongs to type 1 landmarks and Jugale to type 2 landmarks.

Conclusion: The review provides an extensive cross-section of possible landmarks with the definition of the location and the possible location variation. The list of these landmarks should be observed through the classification of landmarks according to their homology and possible classification variations. The proper selection of landmarks in facial analyses of symmetry is of utmost importance and landmarks should be comparable among many studies. As a result of this study, the authors recommend using a specific number of high-value and comparable landmarks to be of great relevance for asymmetry analysis of facial structures.
\end{abstract}

Rupić I, Čuković-Bagić I, Ivković V, Lauc T. Assessment of facial landmarks for bone asymmetry in geometric morphometric studies: a review. South Eur J Orthod Dentofac Res. 2020;7(S1):6-16.

\author{
Corresponding Author: \\ Ivana Rupić \\ Apolonija Dental Clinic \\ Zagreb, Croatia \\ email:ivana.rupic@apolonija.hr
}




\section{INTRODUCTION}

\section{Rationale}

Facial asymmetry is defined as any deviation from the identical shape or size of two sides of the face and is one of the most common facial features. Asymmetry affects facial aesthetics ${ }^{1,2}$ and occlusal function ${ }^{3-5}$, so the assessment of facial asymmetry should be part of the regular facial clinical examination in dental medicine and particularly in orthodontics. Also, the assessment of asymmetry is used in biological anthropology for shape analysis of asymmetry in a study of evolution, especially for assessing developmental instability. ${ }^{6-8}$

The basis for morphometric analyses is anthropometric points or landmarks. Their characteristic is correspondence among specimens or objects in the sample, and if some of them are missing, their position can generally be reconstructed. Landmarks are used to measure the dimensions and interrelationships of individual anatomical structures.

Landmarks' correspondence is often referred to as homology and can be from the common evolutionary origin (i.e., taxic homology) ${ }^{9}$ or anatomical, developmental, or functional correspondence or equivalency (i.e., operational homology). ${ }^{10-13}$ In his fundamental publication from $1991^{14}$, Bookstein defined a classification system based on landmark position and homology that is still referent for their validation. Landmarks are categorized as types 1, 2, or 3 based on their structural and geometrical localisation. ${ }^{14,15}$

Homology of type I landmarks has the strongest evidence, mostly in an anatomical or evolutionary sense. Their position is strict and recognizable, mostly at the juxtaposition of anatomical or histological structures. Type 2 and type 3 are landmarks on anatomical structures with a predominant geometric definition. Where the top of some structure or anatomical curvature can be determined accurately, then we consider landmark type 2 . Type 3 is a landmark that is on the curvature or surface and their position is defined with another, more distant structure. ${ }^{14}$ Still, in many studies, there are undefined criteria for selecting landmarks and the classification of homology. This increases "arbitrarily" selected landmarks are prone to different interpretations. Searching the literature, most authors do not declare the reasons for choosing some landmarks, and most of them do not have a clearly defined classification of homology and the definition itself.

Thus, it is unclear if the results of facial asymmetry assessment performed in different studies can be compared with each other? The noted ambiguities in landmark definition can be avoided by adopting a uniform classification and definition of landmarks. Future facial asymmetry analyses should also choose landmarks that have been used in other studies to increase the external validity of their results. Therefore, there is a need to systematize landmarks used for assessments of facial asymmetry according to the criteria of homology and the frequency of landmark use in scientific research. Also, summarizing the available literature in this field has a practical benefit for investigating facial asymmetry using geometric morphometrics.

\section{Objectives}

This review's objective was to assess which landmarks should be recommended as standard landmarks for facial asymmetry assessments using geometric morphometrics. The use of landmarks that are more commonly represented in the asymmetry analyses can provide a better comparison to the data from other similar studies. In different medical fields such as orthodontics or maxillofacial surgery, for estimation of facial asymmetry, it is of clinical importance to valorize the facial anthropometric point or morphometric landmarks that can be used with greater relevance. Therefore, a modified PRISMA review method was used to review anthropological studies with the methodology used in clinical medicine. This study's final intention was to implement anthropological research within a clinical application in the field of maxillofacial surgery, orthodontics, and esthetic medicine.

\section{MATERIALS AND METHODS}

\section{Protocol and registration}

This review was based on the guidelines provided by the PRISMA statement ${ }^{16}$ and the Cochrane Handbook for Systematic Reviews of Interventions (version 5.1.0) ${ }^{17}$ with adjustments in order to analyze anthropological studies and is available upon request.

\section{Information sources and search}

Electronic searches were conducted for studies published up to March 2020. The reference lists of the articles eligible for inclusion in this review were also manually reviewed. For every database, keyword and Medical Subject Headings (MeSH) terms were carefully chosen, while the search strategy was structured to fit the specific requirements of the respective database. Two authors (IR and TL) conducted the search strategy. Citations of articles published in journals, dissertations and conference proceedings were located from several electronic databases by a search strategy appropriately adjusted for each individual database (Table 1). No restrictions were applied concerning the publication year or status. Only English literature was included in the search.

\section{Eligibility criteria and study selection}

The eligibility criteria were predetermined (Table 2, 3 and Figure 1.). A study was considered eligible when assessing the face and skull's skeleton was done solely on three-dimensional recordings. Studies in which a human ancestor was taken as a control group were not considered. Some of the inclusion criteria were: participants of any age and a clearly defined list of landmarks names. After eliminating duplicates, the selection was made by considering the title and abstract separately by two authors (IR and TL). If any of the two authors selected some study based on the title and abstract, the study was included. 
Table 1. The Electronic Databases Searched and the Search Strategy Used in the Review (as of March 25, 2020)

\begin{tabular}{|c|c|c|}
\hline $\begin{array}{l}\text { Databases of } \\
\text { Published Trials }\end{array}$ & Search Strategy Used & Hits \\
\hline $\begin{array}{l}\text { MEDLINE } \\
\text { searched via } \\
\text { PubMed } \\
\text { www.ncbi.nlm.nih. } \\
\text { gov/sites/entrez }\end{array}$ & $\begin{array}{l}\text { [(randomized controlled trial[pt] OR controlled clinical } \\
\text { trial[pt] OR randomized controlled trials[mh] OR random } \\
\text { allocation[mh] OR double-blind method[mh] OR single- } \\
\text { blind method[mh] OR clinical trial[pt] OR clinical } \\
\text { trials[mh]) OR ("clinical trial"[tw]) OR [(singl*[tw] OR } \\
\text { doubl*[tw] OR trebl*[tw] OR tripl*[tw]) AND (mask*[tw] } \\
\text { OR blind*[tw])) OR (placebos[mh] OR placebo*[tw] } \\
\text { OR random*[tw] OR research design[mh:noexp] OR } \\
\text { comparative study OR evaluation studies OR follow-up } \\
\text { studies [mh] OR prospective studies[mh] OR control*[tw] } \\
\text { OR prospectiv*[tw] OR volunteer*[tw])] AND [(face } \\
\text { asymmetry*) OR (facial asymmetry*) OR (skull } \\
\text { asymmetry*)] AND [(hard tissue*) OR (bone) OR (skeletal)] } \\
\text { AND [(geometric morphometrics*)] AND [(humans)] }\end{array}$ & 16 \\
\hline $\begin{array}{l}\text { EMBASE } \\
\text { searched via } \\
\text { ScienceDirect } \\
\text { www.embase.com }\end{array}$ & $\begin{array}{l}\text { [( [( 'phase-4-clinical-trial'/exp OR 'phase-4-clinical-trial') } \\
\text { OR ('randomized-controltrial') OR ('randomization'/exp OR } \\
\text { 'randomization') OR ('controlled-study'/exp OR 'controlled- } \\
\text { study') OR ('multicenter-study'/exp OR 'multicenter-study') } \\
\text { OR ('phase-3-clinical-trial'/exp OR 'phase-3-clinical-trial') } \\
\text { OR ('double-blind-procedure'/exp OR 'double-blind- } \\
\text { procedure') OR ('single-blind-procedure'/exp OR 'single- } \\
\text { blindprocedure')] OR (random*:ab OR cross?over*:ab } \\
\text { OR factorial*:ab OR placebo*:ab OR volunteer*:ab) } \\
\text { OR (random*t:ti OR cross over*tti OR factorial':ti OR } \\
\text { placebo*:ti OR volunteer*:ti) OR [( singl* OR doubl* OR } \\
\text { trebl* OR tripl*) AND near AND (blind*:ti OR mask*t:ti)] } \\
\text { OR [( singl* OR doubl* OR trebl* OR tripl*) AND near } \\
\text { AND (blind*:ab OR mask*:ab)] ) NOT [( [('animal'/exp } \\
\text { OR 'animal') OR ('nonhuman'/exp OR 'nonhuman')] ) } \\
\text { NOT [( [('animal'/exp OR 'animal') OR ('nonhuman'/exp } \\
\text { OR 'nonhuman')] ) AND ('human'/exp OR 'human')] )] } \\
\text { AND [(face asymmetry*) OR (facial asymmetry*) OR (skull } \\
\text { asymmetry*)] AND [(hard tissue*) OR (bone) OR (skeletal)] } \\
\text { AND [(geometric morphometrics*)] AND [(humans)] }\end{array}$ & 21 \\
\hline $\begin{array}{l}\text { Cochrane Central } \\
\text { Register of } \\
\text { Controlled Trials } \\
\text { searched via The } \\
\text { Cochrane Library }\end{array}$ & $\begin{array}{l}{[(\text { face asymmetry*) OR (facial asymmetry*) OR (skull }} \\
\left.\left.\text { asymmetry }{ }^{*}\right)\right] \text { AND }[(\text { hard tissue* }) \text { OR (bone) OR (skeletal) }] \\
\text { AND }[(\text { geometric morphometrics })] \text { AND }[(\text { humans })]\end{array}$ & 0 \\
\hline $\begin{array}{l}\text { Google Scholar Beta } \\
\text { www.scholar.google. } \\
\text { com }\end{array}$ & $\begin{array}{l}{[(\text { face asymmetry*) OR (facial asymmetry*) OR (skull }} \\
\text { asymmetry*)] AND }\left[\left(\text { hard tissue }^{*}\right) \text { OR (bone) OR (skeletal) }\right] \\
\text { AND }[(\text { geometric morphometrics })] \text { AND }[\text { (humans) }]\end{array}$ & 314 \\
\hline $\begin{array}{l}\text { Databases of } \\
\text { published trials } \\
\text { Web of Science } \\
\text { http://scientific. } \\
\text { thomson.com/ } \\
\text { products/wos/ }\end{array}$ & 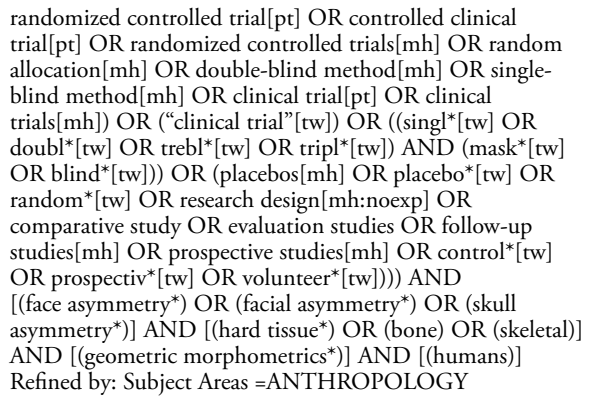 & 46 \\
\hline $\begin{array}{l}\text { Scopus } \\
\text { www. scopus.com }\end{array}$ & $\begin{array}{l}{[(\text { face asymmetry*) OR (facial asymmetry*) OR (skull }} \\
\text { asymmetry })] \text { AND }[(\text { hard tissue* }) \text { OR (bone) OR (skeletal) }] \\
\text { AND }[(\text { geometric morphometrics*) }) \text { AND [(humans) }]\end{array}$ & 8 \\
\hline $\begin{array}{l}\text { Windows Live } \\
\text { Academic } \\
\text { search.live.com }\end{array}$ & $\begin{array}{l}\text { ("face asymmetry" OR "facial asymmetry" OR "skull } \\
\text { asymmetry") and ("hard tissue" OR bone OR skeletal) AND } \\
\text { ("geometric morphometrics") AND ((humans)) }\end{array}$ & 13 \\
\hline $\begin{array}{l}\text { International } \\
\text { Bibliography of } \\
\text { Social and Cultural } \\
\text { Anthropology } \\
\text { via worldcat.org }\end{array}$ & $\begin{array}{l}\text { ("face asymmetry" OR "facial asymmetry" OR "skull } \\
\text { asymmetry") and ("hard tissue" OR bone OR skeletal) AND } \\
\text { ("geometric morphometrics") AND ((humans)) }\end{array}$ & 35 \\
\hline $\begin{array}{l}\text { JSTOR } \\
\text { via www.jstor.org }\end{array}$ & $\begin{array}{l}\text { ("face asymmetry" OR "facial asymmetry" OR "skull } \\
\text { asymmetry") and ("hard tissue" OR bone OR skeletal) AND } \\
\text { ("geometric morphometrics") AND ((humans)) } \\
\text { Subject: Anthropology }\end{array}$ & 31 \\
\hline
\end{tabular}

Table 2. The eligibility criteria inclusion and exclusion

\begin{tabular}{ll}
\hline Inclusion criteria & \multicolumn{1}{c}{ Exclusion criteria } \\
\hline Human participants of any age or gender & $\begin{array}{l}\text { Animal studies } \\
\text { Animal control group }\end{array}$ \\
\hline Facial bone tissue asymmetry assessment & Facial soft tissue or dental arch \\
using GM & Sexual dimorphism \\
& Anatomical variation \\
\hline A Control group is required & A Control group is not required \\
\hline Anthropometric point/landmarks from & Two-dimensional digital images \\
3 D images & \\
\hline Randomized controlled clinical trials (RCTs) & Narrative reviews \\
Prospective controlled clinical trials (CCTs) & Systematic reviews \\
Retrospective controlled cohort studies & Mini reviews \\
Cross-sectional surveys & Case-control observational studies \\
& Case series \\
& Case report \\
The unsupported opinion of an expert \\
& Editor's choices \\
& Books' abstract \\
Conference abstract & Animal studies \\
& Books' chapter \\
Dissertation \\
Books \\
\hline
\end{tabular}

Table 3. Eligibility exclusion criteria used for the study selection

\begin{tabular}{|c|c|c|}
\hline Reason for exclusion & $\begin{array}{l}\text { Excluded articles based on } \\
\text { title and abstract* }\end{array}$ & $\begin{array}{l}\text { Excluded articles based on } \\
\text { full text* }\end{array}$ \\
\hline $\begin{array}{l}\text { Facial soft tissue asymmetry } \\
\text { assessment }\end{array}$ & 16 & 30 \\
\hline Dental Arch asymmetry & - & 1 \\
\hline Narrative review & - & 1 \\
\hline Mini review & - & 1 \\
\hline Systematic review & - & 12 \\
\hline Case report & 6 & 3 \\
\hline $\begin{array}{l}\text { Assessment Homo } \\
\text { floresiensis face }\end{array}$ & 8 & 2 \\
\hline Animal study & 34 & 8 \\
\hline Book chapter & 5 & 2 \\
\hline $\begin{array}{l}\text { Two-dimensional digital } \\
\text { image }\end{array}$ & 25 & 2 \\
\hline Dissertation & 2 & 4 \\
\hline Book & 9 & 3 \\
\hline Sexual dimorphism & 4 & 2 \\
\hline $\begin{array}{l}\text { Anatomical variation of } \\
\text { other parts of the body }\end{array}$ & 19 & 10 \\
\hline $\begin{array}{l}\text { Assessment of only tooth } \\
\text { morphology }\end{array}$ & - & 2 \\
\hline Assessment ears asymmetry & 1 & - \\
\hline Evolution changes & 5 & 3 \\
\hline $\begin{array}{l}\text { Insufficient data about the } \\
\text { analysis landmarks }\end{array}$ & - & 6 \\
\hline
\end{tabular}

*Additional list of excluded studies available upon request 


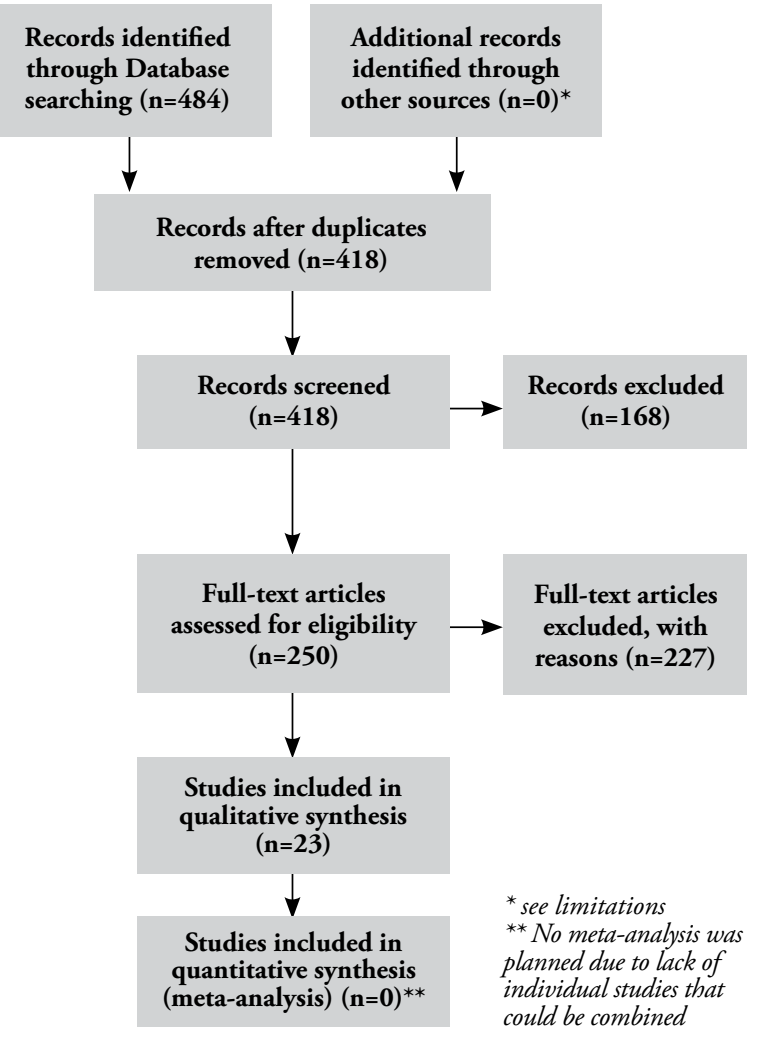

Figure 1. Flow diagram with the number of excluded studies ${ }^{16}$

\section{Data collection process}

Two authors (IR and TL) independently extracted study characteristics and outcomes from the included studies using predefined data extraction forms (Table 4).

Studies that did not have clearly defined names of used landmarks or their position explanations were excluded.

Studies in which the study's subject was the only asymmetry of the arch or individual teeth were also disregarded. All estimates of anatomical variation for sexual dimorphism and evolutionary changes have also been omitted.

The total number of points was counted so that the bilateral points were not numbered as two, but as one marked bilaterally. Landmarks of the included studies were separated into landmarks and semi-landmarks (Table 5, 6).

\section{Risk of bias in included studies}

Since the risk of bias is greatest in defining landmarks' exact positions, Bookstein's three landmark types were used in assessing the risk of bias in each study. Bookstein's classification of landmarks has been interpreted as being qualitative validation of landmarks homology. The implication is that type 1 landmarks are the most suitable for comparative shape analysis, such as facial asymmetry with the weakest risk of bias.

Table 4. Characteristics of the studies included in this study. (ROI- region of interest, NBC - neurobasicranial region, EMC - ethmomaxillary region, $M N$ - mandible, NR-not reported)

\begin{tabular}{|c|c|c|c|c|c|c|c|}
\hline A/A Study & Setting & $\begin{array}{l}\text { Characteristics of patients/ } \\
\text { subjects }\end{array}$ & 3D images & $\begin{array}{l}\text { No of patients, } \\
\text { objects }\end{array}$ & $\begin{array}{l}\text { Number of } \\
\text { landmarks }\end{array}$ & ROI & $\begin{array}{l}\text { Conflict of } \\
\text { interest }\end{array}$ \\
\hline Starbuck et al., $2015 .^{18}$ & University, Indianapolis & $\begin{array}{l}\text { Children with bilateral cleft lip } \\
\text { and palate }\end{array}$ & СBCT & 30 & 20 & EMC, MN & NR \\
\hline Bigoni et al., 2013. ${ }^{19}$ & Faculty of Science, Czech & Adult crania & $\begin{array}{l}\text { MicroScribe G2X } \\
\text { contact digitizer }\end{array}$ & 138 & 39 & EMC & NR \\
\hline Hartman et al., 2016. ${ }^{20}$ & University, Iowa & Adult subjects geographically diverse & CT & 55 & 26 & NBC, EMC & NR \\
\hline Ruskova et al., 2014. ${ }^{21}$ & Faculty of Science, Czech & $\begin{array}{l}\text { Patients with unilateral complete } \\
\text { cleft lip and palate }\end{array}$ & Laser scanner & 58 & 4 & EMC & NR \\
\hline Schlager et al., 2015. ${ }^{22}$ & University, Germany & Scans were taken in two hospitals & CT & 534 & 9 & EMC & NR \\
\hline $\begin{array}{l}\text { Chovalopoulou et al., } \\
2017 .{ }^{23}\end{array}$ & $\begin{array}{l}\text { Laboratory for Archaeological } \\
\text { Science, Greece }\end{array}$ & Adult crania & $\begin{array}{l}\text { Microscribe 3DX } \\
\text { contact digitizer }\end{array}$ & 173 & 77 & NBC, EMC & NR \\
\hline Ibrova et al., $2017 .{ }^{24}$ & Faculty of Science, Czech & Early Medieval skeletal material & $\begin{array}{l}\text { MicroScribe G2X } \\
\text { digitizing system }\end{array}$ & 193 & 20 & $\mathrm{MN}$ & NR \\
\hline Fuessinger et al., 2018. ${ }^{25}$ & University, Freiburg & Adult crania & CT & 131 & 4 & EMC & NR \\
\hline Ceuninck et al., $2019 .{ }^{26}$ & University, Florida & Children and adolescents & CBCT & 24 & 14 & EMC & NR \\
\hline Ridel et al., $2020 .^{27}$ & University, Pretoria & Adult South Africans & CBCT & 10 & 42 & NBC, EMC & NR \\
\hline Jung et al., $2018 .^{28}$ & University, Buffalo, NY & Adult skull & $\begin{array}{l}\text { MicroScribe G2X } \\
\text { digitizing system }\end{array}$ & 74 & 52 & NBC, EMC & NR \\
\hline Espinosa et al., 2019. ${ }^{29}$ & Hospital, Santiago & Hospital patients & CT & 60 & 16 & $\mathrm{MN}$ & NR \\
\hline Weisensee et al., 2018. ${ }^{30}$ & Clemson University, USA & Undocumented border crossers & Microscribe 3DX digitizer & 509 & 14 & EMC & NR \\
\hline Benazzi et al., $2011 .^{31}$ & University, Austria & Skulls & CT & 11 & 162 & EMC & NR \\
\hline Weisensee et al., 2013. ${ }^{32}$ & Clemson University, USA & New Lisbon skeletal collection & Microscribe 3DX digitizer & 392 & 31 & NBC, EMC & NR \\
\hline Katsube et al., 2019. ${ }^{33}$ & University, Japan & Fetus 15 and 20 weeks of gestation & $\mu \mathrm{CT}$ & 21 & 46 & EMC, MN & NR \\
\hline Nur et al., 2016. ${ }^{34}$ & Yeditepe University, Turkey & Patients & CBCT & 89 & 13 & NBC, EMC, MN & NR \\
\hline Nikkhan et al., 2013. ${ }^{35}$ & University, France & Patient with Treacher-Collins syndrome & CT & 39 & 96 & EMC, MN & NR \\
\hline Ridel et al., $2018 .^{36}$ & University, South Africa & Adult South Africans & CBCT & 120 & 12 & EMC & NR \\
\hline Senck et al., $2013 .{ }^{37}$ & University of Austria & Human skull & $\mathrm{CT}$ & 25 & 614 & EMC & NR \\
\hline Ketoff et al., 2016. ${ }^{38}$ & Hospital, France & Skull & CT & 49 & 3 & EMC & NR \\
\hline Ahmad et al., 2018. ${ }^{39}$ & University, Florida & Children & CT & 52 & 23 & EMC & NR \\
\hline Fukase et al., $2015 .^{40}$ & University, Japan & Skull & $\mathrm{CT}$ & 126 & 9 & EMC & NR \\
\hline
\end{tabular}


In contrast, assessment of facial asymmetry using landmarks type 3 represents the most significant risk of bias. Therefore, each landmark from all studies are classified in type 1,2 or 3. To minimize the risk of bias in defining the position of landmarks, the homology classification variation (VOC) category was also used in this review.

Table 5. Landmarks used in included studies

\begin{tabular}{|c|c|c|c|c|}
\hline Study & $\begin{array}{l}\text { Number of } \\
\text { landmarks }\end{array}$ & $\begin{array}{l}\text { Anatomical } \\
\text { landmarks } \\
\text { (Number) }\end{array}$ & Semilandmarks & $\begin{array}{l}\text { Number of } \\
\text { participants/ } \\
\text { subjects }\end{array}$ \\
\hline Starbuck et al., 2015.18 & 20 & 20 & 0 & 30 \\
\hline Bigoni et al., 2013. ${ }^{19}$ & 39 & 39 & 0 & 138 \\
\hline Hartman et al., 2016. ${ }^{20}$ & 26 & 26 & 0 & 55 \\
\hline Ruskova et al., 2014. ${ }^{21}$ & 3 & 3 & 0 & 58 \\
\hline Schlager et al., 2015.22 & 9 & 9 & 0 & 534 \\
\hline Chovalopoulou et al., 2017.33 & 77 & 77 & 0 & 173 \\
\hline Ibrova et al., $2017 .{ }^{24}$ & 20 & 20 & 0 & 193 \\
\hline Fuessinger et al., $2018 .^{25}$ & 4 & 4 & 0 & 131 \\
\hline Ceuninck et al., $2019^{26}$ & 14 & 14 & 0 & 24 \\
\hline Ridel et al., $2020 .{ }^{27}$ & 42 & 42 & 0 & 10 \\
\hline Jung et al., $2018 .^{28}$ & 52 & 52 & 0 & 74 \\
\hline Espinosa et al., 2019.29 & 16 & 16 & 0 & 60 \\
\hline Weisensee et al., 2018. ${ }^{30}$ & 14 & 14 & 0 & 509 \\
\hline Benazzi et al., $2011 .{ }^{31}$ & 157 & 11 & 146 & 162 \\
\hline Weisensee et al., 2013. ${ }^{32}$ & 31 & 31 & 0 & 392 \\
\hline Katsube et al., 2019.33 & 46 & 46 & 0 & 21 \\
\hline Nur et al., 2016. ${ }^{34}$ & 13 & 13 & 0 & 89 \\
\hline Nikkhan et al., $2013 .{ }^{35}$ & 96 & 96 & 0 & 39 \\
\hline Ridel et al., $2018 .^{36}$ & 12 & 12 & 0 & 120 \\
\hline Senck et al., $2013 .^{37}$ & 614 & 47 & 567 & 25 \\
\hline Ketoff et al., $2016 .{ }^{38}$ & 3 & 3 & 0 & 49 \\
\hline Ahmad et al., $2018 .{ }^{39}$ & 23 & 23 & 0 & 52 \\
\hline Fukase et al., $2015 .{ }^{40}$ & 9 & 9 & 0 & 126 \\
\hline
\end{tabular}

Table 6. Semilandmarks used in included studies

\begin{tabular}{lcc}
\hline Curve names & $\begin{array}{c}\text { Semi-Landmarks identified } \\
\text { on Curves Count }\end{array}$ & $\begin{array}{c}\text { Frequency } \\
\text { of occurrence }\end{array}$ \\
\hline Alveolar right & 9 & 1 \\
\hline Alveolar left & 9 & 1 \\
\hline $\begin{array}{l}\text { Lower zygomaticotemporal } \\
\text { outline left }\end{array}$ & 10 & 1 \\
\hline Orbital left & 14 & 1 \\
\hline Orbital right & 8 & 1 \\
\hline $\begin{array}{l}\text { Upper zygomaticotemporal } \\
\text { outline left }\end{array}$ & 15 & 1 \\
\hline Temporal left & 4 & 1 \\
\hline Temporal right & 4 & \\
\hline
\end{tabular}

\section{RESULTS}

The craniofacial system is divided into neurobasicranial region, ethmomaxillary region and the mandible. The results present a list of landmarks distributed among three regions, mostly used in selected studies for three-dimensional assessment of craniofacial asymmetry using geometric morphometrics.

Landmarks without definition were considered as nonrepeatable and were not included in the list. The column Definition represents the definition noted in the study, and the Definition variation represents all other possible variations of the definition of the selected point. Each landmark is classified according to the Bookstein classification.

\section{Landmarks in neurobasicranial region}

Assessment of neurobasicranial asymmetry was conducted in 6 studies and 45 different landmarks were recorded, of which 11 were medial and 34 bilateral. Bregma and Lambda occur most frequently and according to homology, both belong to type 1 landmarks (Table 7.).

\section{Landmarks in ethmomaxillary region}

Assessment of ethmomaxillary asymmetry was conducted in 21 studies and 67 different landmarks were recorded, of which 16 were medial and 52 bilateral. Nasion and Jugale occur most frequently and according to homology Nasion belongs to type 1 landmarks and Jugale to type 2 landmarks.

\section{Landmarks in region mandible}

Assessment of mandibular asymmetry was conducted in 6 studies and 41 different landmarks were recorded, of which 10 were medial and 31 bilateral. The Gonion and Condyle appear the most times/frequently and according to the homology, Gonion belongs to the type 3 landmarks and the Condyle to the type 2 landmarks (Table 9).

\section{DISCUSSION}

\section{Summary of evidence}

A large variety of landmarks is used in geometric morphometric research of facial asymmetry. When using geometric morphometrics to investigate facial asymmetry, all objects or individuals in the sample should have the same set of landmarks that correspond together with the same position relative to other landmarks. ${ }^{42}$ This exact position is of particular importance in symmetry analyses when using bilateral or medial (unilateral) landmarks.

As expected, the ethmomaxilary region has been the subject of most facial asymmetry studies with the widest variety of used landmarks. In all three regions, a variation of landmark types is present with predominant landmarks type 2 . As type 1 landmarks are mostly defined at the juxtaposition of different anatomical structures or bones, they are more often registered among unilateral medial landmarks. For that reason, in the region of mandible landmarks type 1 are very rare. 
Table 7. Landmarks in the neurobasicranial region (Abb. - abbreviation, M/B - midline or bilateral, Definition - definition of landmarks, Class - Bookstein's types or homology classification, VOC-a variation of homology classification, FOC-frequency of occurrence landmarks in included studies)

\begin{tabular}{|c|c|c|c|c|c|c|}
\hline Landmarks & Abb & $\mathbf{M} / \mathbf{B}$ & Definition & Class & VOC & FOC \\
\hline Bregma & brg & M & Intersection of the sutura coronalis and sutura sagittalis in the midsagittal plane. & 1 & None & 8 \\
\hline Lambda & lam & M & Intersection of the sutura sagittalis and lambdoidal sutura in the midsagittal plane. & 1 & None & 8 \\
\hline Glabella & $\begin{array}{l}\text { G, g, GB } \\
\text { or GLB }\end{array}$ & M & $\begin{array}{l}\text { The most prominent point between the supraorbital ridges in the midsagittal plane. } \\
\text { The most anterior midline point on the frontal bone, usually above the frontonasal suture. }\end{array}$ & 2 & 3 & 7 \\
\hline Basion & Bas, ba & M & $\begin{array}{l}\text { Lowest midline point on the anterior margin of the foramen magnum. } \\
\text { The most inferior posterior point in the sagittal plane on the anterior rim of the foramen magnum. }\end{array}$ & 2 & 3 & 6 \\
\hline Asterion & ast & B & Intersection of the sutura lambdoidea, sutura parietomastoidea and sutura occipitomastoidea. & 1 & None & 5 \\
\hline Porion & Po or $\mathrm{P}$ & B & Uppermost point on the margin of the external acoustic meatus. & 3 & 2 & 5 \\
\hline Opisthocranion & ops & M & The midline ectocranial point at the farthest chord length from Glabella. & 2 & 3 & 4 \\
\hline Opisthion & Op or o & M & $\begin{array}{l}\text { The midpoint of the posterior margin of the foramen magnum in the midsagittal plane. } \\
\text { The most posterior point, relative to the interspinosum line, on the border of the foramen magnum. }\end{array}$ & 2 & 1,3 & 4 \\
\hline Auriculare & au & B & Intersection of the base of zygomatic arch and the midline of the opening of the meatus acusticus externus. & 3 & 1 & 3 \\
\hline $\begin{array}{l}\text { Caroticum mediale/Carotid } \\
\text { canal }\end{array}$ & med & B & $\begin{array}{l}\text { The most medial point on the margin of the foramen caroticum externum. } \\
\text { The most medial point on the carotid canal. }\end{array}$ & 3 & None & 3 \\
\hline Sphenion & sph & B & Intersection of the sutura coronalis, sutura sphenoparietalis, and sutura sphenofrontalis. & 1 & 3 & 3 \\
\hline Suture line ZT & $\mathrm{ZT}$ & B & Midpoint of the zygomaticotemporal suture. & 3 & None & 3 \\
\hline Stephanion & None & B & The point where the coronal suture crosses the (inferior) temporal line. & 2 & 1 & 3 \\
\hline Carotid canal (lat) & lat & B & The most lateral point on the carotid canal. & 3 & None & 2 \\
\hline Coronale & cor & B & One of the two most widely separated points on the sutura coronalis at the poles of the greatest frontal diameter. & 3 & None & 2 \\
\hline Crotaphion & cro & B & Intersection of the sutura sphenosquamosa, sutura sphenoparietalis and sutura squamosa. & 1 & None & 2 \\
\hline Entomion & ent & B & The point, where the sutura squamosa passes into sutura parietomastoidea. & 1 & None & 2 \\
\hline Foramen ovale & pos & B & The most posterior point on the foramen ovale. & 3 & None & 2 \\
\hline Foraminolaterale & fl & B & The most lateral point on the margin of the foramen magnum. & 3 & None & 2 \\
\hline Hormion & hor & M & $\begin{array}{l}\text { Intersection of the midsagittal plane and the line where the base of the vomer meets os sphenoidale. } \\
\text { The junction of the posterior border of the lateral pterygoid plate with the lower border of the posterior cranial base. }\end{array}$ & 1 & None & 2 \\
\hline Krotaphion & kro & B & The most posterior extent of the sphenoparietal suture. & 1 & None & 2 \\
\hline Occipitocondylion anterior & Occ ant & B & The most anterior point on the margin of the condylus occipitalis. & 3 & None & 2 \\
\hline Occipitocondylion laterale & Occ lat & B & The most lateral point on the margin of the condylus occipitalis. & 3 & None & 2 \\
\hline Ovale mediale & om & B & The most medial point on the margin of the foramen ovale. & 3 & None & 2 \\
\hline Sphenomaxillare & Sph sup & M & The most superior, lateral point of contact between the maxilla and the lateral pterygoid plate of the sphenoid. & 3 & None & 2 \\
\hline Stenion & ste & B & The most medial point on sphenosquamosal sutures. & 3 & None & 2 \\
\hline External palate length & Expl & B & The point on the inferior surface of the maxilla that denotes the most posterior point of the alveolar process. & 3 & None & 1 \\
\hline Foramen magnum & $\mathrm{fm}$ & B & The most lateral point on the margin of the foramen magnum. & 3 & None & 1 \\
\hline Foramen jugulare & fi & B & The most lateral point on the margin of the foramen jugulare. & 3 & None & 1 \\
\hline Foramen ovale (ant) & Fo ant & B & The most anterior point on the foramen ovale. & 3 & None & 1 \\
\hline Infratemporale & it & B & Intersection of the sutura sphenosquamosa and crista infratemporalis of the sphenoid bone. & 1 & None & 1 \\
\hline Landmark $\mathrm{x}$ & $\mathrm{x}$ & B & Intersection of the sutura sphenozygomatica, sutura sphenofrontalis and sutura frontozygomatica. & 1 & None & 1 \\
\hline Maxillonasofrontale & $\mathrm{mnf}$ & B & Intersection of the sutura frontonasalis, sutura frontomaxillaris and sutura nasomaxillaris. & 1 & None & 1 \\
\hline Occipital protuberance & None & B & Most prominent part of the occipital bone at the posteroinferior part of the skull. & 2 & None & 1 \\
\hline Occipitocondylion mediale & None & B & The most medial point on the margin of the condylus occipitalis. & 3 & None & 1 \\
\hline Occipitocondylion posterior & None & B & The most posterior point on the margin of the condylus occipitalis. & 3 & None & 1 \\
\hline Petrosal & $\mathrm{pt}$ & B & The most anterior point of the petrous element of the temporal bone. & 2 & None & 1 \\
\hline Piriform aperture & ap & B & Apex of the nasal aperture. & 2 & None & 1 \\
\hline Piriform curvature & $\mathrm{cp}$ & B & Most infero-lateral point of the piriform aperture. & 3 & None & 1 \\
\hline Sela & S or $s$ & M & Center of the hypophyseal fossa. & 3 & None & 1 \\
\hline Spinale & $\mathrm{sp}$ & B & The most medial point on the margin of the foramen spinosum. & 3 & None & 1 \\
\hline Staurion & sta & M & The point of intersection of the median and transverse palatine sutures. & 3 & None & 1 \\
\hline Staphylion & sph & M & The point where the interpalatal suture intersects a line joining the deepest indentation of the posterior Palate. & 2 & 1 & 1 \\
\hline Styloid foramen & sf & B & The most anterior, inferior point on the styloid foramen. & 2 & None & 1 \\
\hline $\begin{array}{l}\text { Supramastoid crest-squamous } \\
\text { suture intersection }\end{array}$ & None & B & Point at which the frontozygomatic suture intersects the inner orbital rim. & 1 & None & 1 \\
\hline
\end{tabular}


Table 8. Landmarks in the ethmomaxillary region (Abb. - abbreviation, M/B - midline or bilateral, Definition - definition of landmarks, Class - Bookstein's types or homology classification, VOC - variation of homology classification, FOC-frequency of occurrence landmarks in included studies).

\begin{tabular}{|c|c|c|c|c|c|c|}
\hline Landmarks & Abb & $\mathbf{M} / \mathbf{B}$ & Definition & Class & VOC & FOC \\
\hline Nasion & $\mathrm{n}$ or NA & $\mathrm{M}$ & Superior midline intersection of the nasal bones. The middle of the sutura nasofrontalis in the midsagittal plane. & 1 & None & 17 \\
\hline Jugale/jugulare & ju or J & B & $\begin{array}{l}\text { The point in the depth of the notch between the temporal and frontal processes of the zygomatic bone. } \\
\text { The point at the union of the processus frontalis and processus temporalis of the os zygomaticus. }\end{array}$ & 2 & None & 12 \\
\hline Alare & al or alar & B & Instrumentally determined as the most lateral point on the nasal aperture in a transverse plane. & 3 & None & 10 \\
\hline Rhinion & rhi or $\mathrm{R}$ & $\mathrm{M}$ & The anterior tip of the nasal bones. The most anterior inferior point on the tips of the nasal bone as seen from norma lateralis. & 2 & None & 10 \\
\hline Zygomaxillare & $\mathrm{ZM}$ & B & $\begin{array}{l}\text { The most inferior point of the zygomaticomaxillary suture. } \\
\text { A craniometric point located externally at the lowest extent of the zygomaticomaxillary suture. }\end{array}$ & 1 & 2 & 10 \\
\hline Ectoconchion & ecco & B & The most lateral point on the lateral orbital margin. & 2 & 1,3 & 8 \\
\hline Prosthion & pror pro & M & $\begin{array}{l}\text { Median point between the central incisors on the anterior most margin. } \\
\text { The most anterior point on the maxillary alveolar process in the midline. }\end{array}$ & 1 & 2 & 8 \\
\hline Anterior nasal spine & ans & M & $\begin{array}{l}\text { The anterior most pointed projection of the intermaxillary suture. } \\
\text { A pointed projection at the anterior extremity of the intermaxillary suture; the tip. }\end{array}$ & 2 & None & 7 \\
\hline Frontomalare orbitale & frontoorbit & B & Intersection of the sutura frontozygomatica and the lateral margin of the orbit. Relating to the frontal and zygomatic bones. & 2 & 1,3 & 7 \\
\hline Frontomalare temporale & frontotemp & B & The most posterior/lateral point on the sutura frontozygomatica. The most anterior point of the linea temporalis on the os frontalis. & 2 & 1,3 & 7 \\
\hline Ectomolare & ect & B & Positioned at the most lateral point on the lateral surface of the alveolar crest. Found along the second molar on the maxilla. & 3 & 2 & 6 \\
\hline $\begin{array}{l}\text { Zygotemporale superior/ } \\
\text { zygomatic arch }\end{array}$ & za & B & $\begin{array}{l}\text { The most superior point on the sutura Zygomaticotemporalis. } \\
\text { Most anterior, lateral, and midpoint of the zygomaticomaxillary suture on the zygomatic arch. }\end{array}$ & 2 & None & 6 \\
\hline Mastoidale & mast & B & The most inferior point on the processus mastoideus. & 2 & 1 & 5 \\
\hline Maxillofrontale & $\mathrm{mf}$ & B & $\begin{array}{l}\text { Intersection of sutura frontomaxillaris and the Anterior lacrimal crest. Estimated by the point on the suture closest to } \\
\text { the point where the orbital rim flattens. Intersection of the sutura frontomaxillaris and the medial margin of the orbit. }\end{array}$ & 1 & None & 5 \\
\hline Nasospinale & ns & $\mathrm{M}$ & $\begin{array}{l}\text { Intersection of the subtence/chord inferior margins of the apertura piriformis and the midsagittal plane. The point } \\
\text { of intersection of a line uniting the lowest points on the margin of each nasal opening with the midsagittal plane. }\end{array}$ & 1 & 2 & 5 \\
\hline Orbitale & or or orb & B & $\begin{array}{l}\text { Most inferior point on the inferior orbital rim. Usually falls along the lateral half of the orbital margin. } \\
\text { The lowest point on the lower edge of the cranial orbit. }\end{array}$ & 3 & 1,2 & 5 \\
\hline Zygotemporale inferior & zyti & B & $\begin{array}{l}\text { The most inferior point on the sutura Zygomaticotemporalis. } \\
\text { Lowest point of the zygomaticotemporal suture, at the top of the zygomatic tubercle. }\end{array}$ & 2 & None & 5 \\
\hline A point/subspinale & A or ss & $\mathrm{M}$ & $\begin{array}{l}\text { The deepest point seen in the profile view below the anterior nasal spine (orthodontic point A). } \\
\text { The most posterior point on the curvature from the anterior nasal spine to the crest of the maxillary alveloar process. }\end{array}$ & 3 & None & 4 \\
\hline Infraorbitale & ib & B & The most lateral point on the margin of the foramen infraorbitale. & 2 & None & 4 \\
\hline Apertion & Aper & B & The most lateral point on the nasal aperture. & 3 & None & 3 \\
\hline $\begin{array}{l}\text { Articular eminence/Articulare } \\
\text { eminence/Articulare }\end{array}$ & $\mathrm{Ar}$ & B & $\begin{array}{l}\text { Point posterior to the inferior point of the tubercle of the zygoma. } \\
\text { The points intersection of the dorsal contours of the process articularis mandibulae and os temporalis. }\end{array}$ & 2 & None & 3 \\
\hline Endoconchion & enco & B & The most medial point on the medial orbital margin. & 3 & None & 3 \\
\hline Frontale & ftle & $\mathrm{B}$ & The point of medial most constriction of the frontal bone superior to the lateral orbital rim. & 1 & None & 3 \\
\hline Dacryon & dac & B & Point where frontolacrimal and lacrimomaxillary sutures intersect. & 1 & None & 3 \\
\hline Infra M1 & $\operatorname{Im} 1$ & $\mathrm{~B}$ & The point located on the alveolar process at the level of the middle of the first lower molar. & 1 & None & 3 \\
\hline Labrale Superius & ls & M & $\begin{array}{l}\text { The midline point at the most anterior edge of the superior alveolar ridge of the maxillae, centered between the } \\
\text { maxillary central incisors at the level of the cementum-enamel junction. }\end{array}$ & 3 & None & 3 \\
\hline Mid-Infraorbital & mio & B & Centered lower part of the margin of the orbit. & 3 & None & 3 \\
\hline Mid-Supraorbital & mso & B & The centered upper part of the orbital margin. & 3 & None & 3 \\
\hline Nariale & nar & B & Beginning of the transition of the lower border of the apertura nasalis into the structure of the nasospinale. & 3 & None & 3 \\
\hline Nasale inferius & nlhi & B & Most inferior point on nasal aperture. & 2 & None & 3 \\
\hline Zygoorbitale & zo & B & Intersection of the orbital margin and the zygomaticomaxillary suture. & 1 & None & 3 \\
\hline Zygomatico-frontale (zygo) & zygo & B & Intersection of zygomaticomaxillary suture at orbital margin. & 1 & None & 3 \\
\hline Canine & $\mathrm{cn}$ & B & Mesial to C, alveolar border. & 3 & None & 2 \\
\hline Incisivon & incs & $\mathrm{M}$ & The most posterior inferior point on the incisive fossa. & 2 & None & 2 \\
\hline Lateral border nasal aperture & lbna & B & The most lateral point on the lateral border of the nasal aperture. & 3 & None & 2 \\
\hline Palatomaxillare & $\mathrm{p} \operatorname{lmx}$ & $\mathrm{M}$ & The point of intersection of the palatine and the maxillary bones. & 1 & None & 2 \\
\hline Subconchion & Sub co & $\mathrm{B}$ & Intersection of the inferior margin of the orbit and normal to the line $\mathrm{mf}-\mathrm{ec}$. & 1 & None & 2 \\
\hline Supraconchion & Supra co & B & Intersection of the superior margin of the orbit and normal to the line mf-ec. & 1 & None & 2 \\
\hline Akantion & ak & $\mathrm{M}$ & Most anterior midline point of the nasal spine. & 3 & None & 1 \\
\hline Alveolon & alv & $\mathrm{M}$ & The point where the interpalatal suture intersects the line joining the posterior margins of the alveolar Proces. & 3 & None & 1 \\
\hline $\mathrm{C} / \mathrm{P} 3$ & None & B & The most inferior external point between the maxillary canine and the first pre-molar. & 3 & None & 1 \\
\hline Foramen incisivum & fi & $\mathrm{M}$ & The most anterior points of the bone ridge of foramen incisivum. & 1 & None & 1 \\
\hline Foramen infraorbitale & finfra & $\mathrm{B}$ & The most anterior points of the bone ridge of foramen infraorbitale. & 1 & None & 1 \\
\hline Foramen palatinum majus & fpm & B & The most anterior points of the bone ridge of foramen palatinum majus. & 1 & None & 1 \\
\hline FRED & None & $\mathrm{B}$ & The point of intersection of the frontozygomatic, zygomaticosphenoid and sphenofrontal sutures. & 1 & None & 1 \\
\hline Frontomalare anterior & fma & B & Most lateral point on fronto-malar suture. & 2 & None & 1 \\
\hline Incisive fossa & - & B & Just below incisor teeth; most concave depression incisive fossa. & 3 & None & 1 \\
\hline
\end{tabular}


Table 8. Cont'd

\begin{tabular}{|c|c|c|c|c|c|c|}
\hline Landmarks & Abb & M/B & Definition & Class & VOC & FOC \\
\hline Labrale Inferius & Il & M & $\begin{array}{l}\text { The midline point at the most inferior edge of the inferior alveolar ridge of the mandible, centered between the } \\
\text { mandibular central incisors at the level of the cementum-enamel junction. }\end{array}$ & 3 & None & 1 \\
\hline Mastoidale (ant) & Mst ant & $\mathrm{B}$ & The anterior point of intersection of the mastoid process and the external tympanic plate. & 2 & None & 1 \\
\hline Mastoidale (post) & Mst post & $\mathrm{B}$ & The posterior point of intersection of the mastoid process and the digastric groove. & 2 & None & 1 \\
\hline Max maxillary curve & None & B & The point in the depth of the notch between the zygomaxillary suture and the alveolar process. & 3 & None & 1 \\
\hline Mid nasal & $\mathrm{mn}$ & M & Midline point on the internasal suture midway between Nasion and Rhinion. & 3 & None & 1 \\
\hline Nasomaxillare & $\mathrm{nm}$ & $\mathrm{B}$ & Most inferior point of the nasomaxillary suture on the nasal aperture. & 3 & None & 1 \\
\hline Nasomaxillofrontale & $\mathrm{nmf}$ & B & Point at the intersection of the frontal, maxillary, and nasal bones. & 1 & None & 1 \\
\hline Orbitale (sup) & O sup & $\mathrm{B}$ & The most superior midpoint of the orbital margin. & 3 & None & 1 \\
\hline Orbitolateral corner & O lat & B & Point on the inner orbital rim where the lower margin of the orbit meets the lateral margin of the orbit. & 3 & None & 1 \\
\hline Posterior nasal spine & PNS & M & The most posterior point at the sagittal plane on the bony hard palate. & 2 & None & 1 \\
\hline Submaxillare curvature & $\mathrm{csm}$ & $\mathrm{B}$ & Most supero-medial point on the maxillary inflexion between the zygomaxillare and the ectomolar. & 2 & None & 1 \\
\hline Supra canine & sc & $\mathrm{B}$ & Point on the superior alveolar ridge superior to the crown of the maxillary canine. & 3 & None & 1 \\
\hline Supra M1 & $\operatorname{sm} 1$ & $\mathrm{~B}$ & The point located on the alveolar process at the level of the middle of the first upper molar. & 3 & None & 1 \\
\hline Supra M2 & sm2 & $\mathrm{B}$ & $\begin{array}{l}\text { The point located on the most lateral portion of the alveolar process at the level of the middle of the second upper } \\
\text { molar or if missing or not fully erupted then where the second molar would be. }\end{array}$ & 1 & None & 3 \\
\hline Supraorbital notch & None & $\mathrm{B}$ & Point of greatest concavity on the supraorbital notch. & 1 & None & 3 \\
\hline Suture line $\mathrm{ZT}$ inferior line & None & B & Most inferior point of the zygomaticotemporal suture. & 2 & None & 1 \\
\hline Suture line ZT superior & None & $\mathrm{B}$ & Most superior point of the zygomaticotemporal suture. & 2 & None & 1 \\
\hline Zygion & zyg & $\mathrm{B}$ & Most lateral point on zygomatic arch. & 2 & None & 1 \\
\hline Zygomatic arch & Zyg arch & $\mathrm{B}$ & Midpoint between M1 and O1. & 3 & None & 1 \\
\hline
\end{tabular}

\section{Neurobasicranial region}

The most common bilateral landmarks used in the assessment of asymmetry were Asterion (type 1) and Porion (type 3)reported in 5 studies, followed by Auriculare (type 3), Caroticum mediale/Carotid canal (type 3), Sphenion (type 1), Suture line ZT (type 3), and Stephanion (type 2) —reported in 3 studies. The most common medial landmarks were Bregma (type 1) and Lambda (type 1) —reported in 8 studies, followed by Glabela (type 3)-reported in 7 studies, Basion (type 2)-reported in 6 studies, and finally, Opisthocranium (type 2) and Opisthion (type 2)-reported in 4 studies. The neurobasicranial regional landmarks of Bookstein type 1 used in more than two studies included Asterion and Sphenion as bilateral and Bregma and Lambda as medial landmarks.

\section{Ethmomaxillary region}

The most common bilateral landmarks used in the assesment of asymmetry were Jugale (type 2)-reported in 12 studies, Alare (type 3) and Zygomaxillare (type 2)-reported in 10, Ectoconchion (type 3) -reported in 8, Frontomalare orbitale (type 2), Frontomalare temporale (type 2) and Frontotemporale (type 1)—reported in 7, Ectomolare (type 3) and Zygotemporale superior (type 2)-reported in 6, Mastoidale (type 2), Maxillofrontale (type 1), Orbitale (type 3) and Zygotemporale inferior (type 2)-reported in 5, Infraorbitale (type 2) in 4, Apertion (type 3), Articular eminence (type 2), Endoconchion (type 3), Frontale (type 1), Dacryon (type 1), Infra M1 (type 1), Mid-Infraorbital (type 3), Mid-Supraorbital (type 3), Nariale (type 3), Nasale inferious (type 2), Zygoorbitale (type 1), Zygomatico-frontale (type 1) -reported in 3 studies.

The most common medial landmarks were Nasion (type 1) - reported in 17 studies, Rhinion (type 2)-reported in 10, Prosthion (type 3) -reported in 8, Anterior nasal spine (type 2)—reported in 7, Nasospinale (type 3) —reported in 5, A point/subspinale (type 3)-reported in 4, and Labrale Superius (type 3)-reported in 3 studies. Finally, Bookstein type 1 landmarks belonging to the ethmomaxillary region of the midface neurobasicranial that were used in more than 2 studies included Frontotemporale, Maxillofrontale, Frontale, Dacryon, Infra M1, Zygoorbitale and Zygomatico-frontale (bilateral) and Nasion as a medial landmark.

\section{Region mandible}

The most common bilateral landmarks used in the assessment of asymmetry were Gonion lateralis (type 2)-reported in 5 studies, Condyle (type 2)-reported in 4, and Coronion (type 2), Mental foramen (type 2) -reported in 3 studies. The most common medial landmarks were Mention (type 3) and Pogonion (type 3) -reported in 3 studies. The type 1 landmarks used to assess mandibular asymmetry included bilateral Hypoglossal foramen-reported in two studies, and bilateral Root of sigmoid notch—reported in one study. 
Table 9. Landmarks in region mandible Abb. - abbreviation, $M / B$ - midline or bilateral, Definition - definition of landmarks, Class - Bookstein's types or homology classification, VOC - a variation of homology classification, FOC - frequency of occurrence landmarks in included studies).

\begin{tabular}{|c|c|c|c|c|c|c|}
\hline Landmarks & Abb & $\mathbf{M} / \mathbf{B}$ & Definition & Class & VOC & FOC \\
\hline Gonion/gonion lateralis & $\begin{array}{l}\text { Gon/ } \\
\text { Golat }\end{array}$ & B & $\begin{array}{l}\text { Point located on the jawline at the level of the angle between the posterior and the inferior borders of the mandible. } \\
\text { The most lateral external point of junction of the horizontal and ascending rami of the lower jaw. }\end{array}$ & 3 & None & 5 \\
\hline Condyle/Condylion & $\mathrm{Co} / \mathrm{CO} / \mathrm{Cd}$ & B & Uppermost point of condyle. The most posterior superior point on the condyle of the mandible. & 2 & None & 4 \\
\hline Coronion/coronoid process & $\mathrm{CP}$ & B & Most superior point on coronoid process. The most superior point of the outlines of the coronoid process. & 2 & None & 3 \\
\hline Mental foramen & MF & $\mathrm{B}$ & Most anterior point of mental foramen. & 2 & None & 3 \\
\hline Menton & Me & M & Most inferior point of the mandibular symphysis. Most inferior points on the symphysis in the mediane plane. & 3 & None & 3 \\
\hline Pogonion & $\begin{array}{l}\text { Po, Pog } \\
\text { or P }\end{array}$ & M & $\begin{array}{l}\text { The most anterior midline point on the mental eminence of the mandible. } \\
\text { Most anterior projection of bone on mental symphysis. }\end{array}$ & 3 & None & 3 \\
\hline Gnathion & $\mathrm{GN}$ or $\mathrm{Gn}$ & $\mathrm{M}$ & Most inferior midline point on symphysis. The most anterior inferior points of the chin. & 3 & None & 2 \\
\hline Hypoglossal foramen & None & B & The most superior, anterior point on the edge of the hypoglossal canal. & 1 & None & 2 \\
\hline Infradentale & Id & M & $\begin{array}{l}\text { Midline point at the superior tip of the septum between mandibular central incisors. } \\
\text { The most anterior-superior points on the labial crest on the mandibular alveolar process. }\end{array}$ & 3 & None & 2 \\
\hline Mandibular notch & None & B & Most concave point of mandibular notch. & 3 & None & 2 \\
\hline Mental protuberance/Menton & $\mathrm{Pm}$ & B & $\begin{array}{l}\text { Most lateral end of mental protuberance. Point above pogonion at top of crest of the symphysis or at a point of } \\
\text { recess of the anterior symphysial curvature - also may be called suprapogonion. }\end{array}$ & 2 & None & 2 \\
\hline Oblique line of the mandible & None & $\mathrm{B}$ & Point on oblique line (external oblique ridge) at the vestibular tissue of the second molar. & 3 & None & 2 \\
\hline Postalverion/posterior alveolar & None & B & Most posterior point situated in the labial surface behind the most posterior erupted tooth or crypt of tooth. & 3 & None & 2 \\
\hline Ramus anterior & None & B & Junction of anterior border of ramus and alveolus. & 3 & None & 2 \\
\hline Antegonion & $\mathrm{Ag}$ & $\mathrm{B}$ & Deepest point of the concavity between the mandibular corpus and the ramus junction. & 3 & None & 1 \\
\hline Condylion medialis & Co med & B & Point where mandibular notch intersects condyle. & 3 & None & 1 \\
\hline Condylion lateralis & Co lat & B & Most lateral point on mandibular condyle. & 3 & None & 1 \\
\hline $\begin{array}{l}\text { First molar/lower molar mesial } \\
\text { contact }\end{array}$ & LMC & B & $\begin{array}{l}\text { Mesial to M1, alveolar border. } \\
\text { The mesial contact of the mandibular first molar. }\end{array}$ & 3 & None & 1 \\
\hline Genion & Ge & M & $\begin{array}{l}\text { Most superior aspect of mental spine. } \\
\text { The most inward and everted point on the profile curvature of the symphysis of the mandible. }\end{array}$ & 3 & None & 1 \\
\hline Gonion inferius & Goinf & B & Most inferior point between the mandibular corpus and the ramus junction. & 3 & None & 1 \\
\hline Gonion posterius & Gopost & B & Most posterior point between the mandibular corpus and the ramus junction. & 3 & None & 1 \\
\hline Incisurale & None & B & Most inferior point on mandibular notch. & 3 & None & 1 \\
\hline Interdentale inferius & None & M & Junction between the lower two incisors. & 3 & None & 1 \\
\hline Lingulare & None & B & Highest positioned point of the lingula of the mandible on the inner side of the mandibular ramus. & 3 & None & 1 \\
\hline Mandibular border 1 & None & B & $\begin{array}{l}\text { Point at lower border of the body of the mandible, on the line passing through coronoid tip parallel the line linking } \\
\text { the gonion and the mandibular notch. }\end{array}$ & 3 & None & 1 \\
\hline Mandibular border 2 & None & B & Point at lower border of the body of the mandible, at half distance between the menton and mandibular border. & 3 & None & 1 \\
\hline Mandibular foramen & MF & B & $\begin{array}{l}\text { Most concave point of the medial border of the mandibular foramen. } \\
\text { The most superior point of the outline of the mandibular foramen. }\end{array}$ & 3 & None & 1 \\
\hline Mental eminence canine & None & B & Most concave portion of the canine eminence. & 3 & None & 1 \\
\hline Mental spines & None & M & Superior end between upper mental spines. & 2 & None & 1 \\
\hline Mental tubercle & None & B & Most superior aspect of the triangular eminence. & 2 & None & 1 \\
\hline Mentale & None & B & Anteromedial edge of mental foramen. & 2 & None & 1 \\
\hline Mentolabial sulcus & $\mathrm{mls}$ & M & The deepest midline point in the groove superior to the mental eminence. & 3 & None & 1 \\
\hline Point B (supramentale) & B & M & $\begin{array}{l}\text { Most concave point on the alveolar process below the apex of the roots of the } 2 \text { central incisors. On a line perpendicular } \\
\text { to } \mathrm{FH} \text {, point } \mathrm{B} \text { is the most posterior point in the concavity between the chin and mandibular alveolar process. }\end{array}$ & 2 & None & 1 \\
\hline Posterior anterior ramus & par & B & The most posterior point along the curved anterior margin of the ascending ramus. & 3 & None & 1 \\
\hline Postgonion & None & B & Most posterior external point on the mandibular branch above the point gonion. & 3 & None & 1 \\
\hline Pregonion & None & B & Most external point at the border of mandibular angle and mandibular body before the point gonion. & 3 & None & 1 \\
\hline Ramus posterior & None & B & Point at posterior border of the mandibular ramus, on the line passing through mental spines and mandibular foramen. & 3 & None & 1 \\
\hline Root of sigmoid process & None & B & Point where mandibular notch intersects condyle. & 1 & None & 1 \\
\hline Supramentale & None & M & Deepest point at the mandibular symphysis curvature between the infradentale and pogonion landmarks. & 3 & None & 1 \\
\hline M3 & None & B & Mesial to the third molar, alveolar border. & 3 & None & 1 \\
\hline
\end{tabular}

\section{Limitations}

One of the limitations of this systematic review is that it includes a relatively small number of studies that deal with the three-dimensional assessment of whole-face asymmetry. The preponderance of identified studies investigates the asymmetry of only one part of the face. The smaller the anatomical region of the facial skeleton on which the asymmetry is determined implies the more extensive and more diverse the list of used landmarks in terms of homology. That means that landmarks of a lower degree of homology in such studies are considered in asymmetry assessment. Warmlander ${ }^{41}$ stresses that landmarks should be chosen to comprehensively represent the morphology 
of the region or features of interest and that landmark placement must be reliable and repeatable. This leads to the next limitation of this review: The reported positions of the same landmarks used in different studies often vary, wherein most studies do not provide a rationale for choosing the specific landmark positions. Also, we notice that individual landmarks do not have a clear definition of their position in some studies. ${ }^{33,37,43}$ These discrepancies limit comparisons between individual landmarks with the same name among different studies.

Finally, the limitation of this review is that it does not include other sources than nine databases, selection criteria and studies published in English. Trial registries, grey literature sources, hand searching, backward search including references of included studies, forward search in citation databases, and search for conference abstracts were not included and can be recognized as a potential publication bias.

\section{CONCLUSION}

The selection and definition of craniofacial hard tissue landmarks is one of the most important tasks in designing morphometric studies assessing facial asymmetry. This review provides an extensive cross-section of possible landmarks with respective definitions of their locations and the possible location variations.

Our analysis showed that a relatively small number of landmarks were represented in a larger number of studies. In the region of neurobasicranium bilateral landmarks Asterion and Porion and unilateral Bregma, Lambda, Glabella and
Basion are reported as most often used. In the region of ethmomaxillary complex bilateral Jugale, Alare, Zygomaxillare, Ectoconchion, Frontomalare orbitale, Frontomalare temporale and Frontotemporale are the most frequently used in researches. Unilateral landmark Nasion is the most represented landmark. Other most common medial landmarks of the middle face are Rhinion, Prosthion and Anterior nasal spine. The most common landmarks in the mandible are Gonion lateralis and Condyle as medial, and Menton and Pogonion as bilateral landmarks.

The proper selection of landmarks in facial analyses of symmetry is of utmost importance and landmarks should be comparable among many studies. Also, landmarks should be observed according to their homology, as well as possible variations of the classification. As a result of this study, authors can recommend that using the distinct number of high-value and comparable landmarks is of great relevance for asymmetry analysis of facial structures.

\section{ACKNOWLEDGEMENT}

All landmarks, abbreviations and definitions used in tables 7-9 are from references 18-41.

The Information sources and search of this protocol/review is based on a standard template used by Cochrane (Cochrane Handbook for Systematic Reviews of Interventions 5.1.0.).

\section{CONFLICT OF INTEREST}

The authors of the present article declare no conflicts of interest. 


\section{REFERENCES}

1. Olivieri P, Uribe FA, Quereshy FA. Aesthetic Facial Surgery and Orthodontics: Common Goals. Oral Maxillofac Surg Clin North Am. 2020;32(1):153-65.

2. Thiesen G, Gribel BF, Freitas MP. Facial asymmetry: a current review. Dental Press J Orthod. 2015;20(6):110-25.

3. Corruccini RS, Potter RH. Genetic analysis of occlusal variation in twins. Am J Orthod. 1980;78:140-54.

4. Sahu A, Lall R, Nezam S, Singh R, Kumar SB, Ayub FB. Comparative Assessment of Facial Asymmetry in Malocclusion using Posteroanterior View. J Contemp Dent Pract. 2018;19(6):712-18.

5. Castelo PM, Pereira LJ, Andrade AS, Marquezin MC, Gaviáo MB. Evaluation of facial asymmetry and masticatory muscle thickness in children with normal occlusion and functional posterior crossbite. Minerva Stomatol. 2010;59(7-8):423-30.

6. Parsons PA. Fluctuating asymmetry: A biological monitor of environmental and genomic stress. Heredity (Edinb). 1992;68:361-4.

7. Gangestad SW, Thornhill R. Individual differences in developmental precision and fluctuating asymmetry: a model and its implication. J Evol Biol. 1999;12:402-16.

8. Polak M. Developmental instability, causes and consequences. 1st ed. Oxford: Oxford University Press; 2003.

9. Smith GR. Homology in morphometrics and phylogenetics. In: Rohlf FJ and Bookstein FL. Proceedings of the Michigan Morphometrics Workshop. Ann Arbor, MI: The University of Michigan Museum of Zoology; 1990.

10. Roth VL. On three-dimensional morphometrics, and on the identification of landmark points. In: Marcus L, Bello E, Valdecasas AG. Advances in morphometrics. Madrid, Spain: Museo Nacional de Ciencias Naturales; 1993.

11. Lele SR, Richtsmeier JT. An invariant approach to statistical analysis of shapes. 1 st edition. Boca Raton: Chapman \& Hall/CRC; 2001.

12. Zelditch M, Swiderski D, Sheets H. Geometric morphometrics for biologists: A primer. 2nd ed. New York: Elsevier Academic Press; 2012.

13. Shearer BM, Cooke SB, Halenar LB, Reber SL, Plummer JE, Delson E. et al. Evaluating causes of error in landmark-based data collection using scanners. PLoS One. 2017;12(11):e0187452.

14. Bookstein FL. Morphometric tools for landmark data. 1st ed. Cambridge: Cambridge University Press; 1991.

15. Bookstein FL. Landmark methods for forms without landmarks: morphometrics of group differences in outline shape. Med Image Anal. 1997;1(3):225-43.

16. Moher D, Liberati A, Tetzlaff J, Altman DG; PRISMA Group. Preferred reporting items for systematic reviews and meta-analyses: the PRISMA statement. PLoS Med. 2009;6(7):e1000097.

17. Higgins JPT, Green S, editors. Cochrane handbook for systematic review of interventions (version 5.1. 0, updated March 2011). The Cochrane Collaboration; 2011. Available at: www-cochrane-handbook.org.

18. Starbuck JM, Ghoneima A, Kula K. Bilateral cleft lip and palate: A morphometric analysis of facial skeletal form using cone beam computed tomography. Clin Anat. 2015;28(5):584-92.

19. Bigoni L, Krajiček V, Sládek V, Velemínský P, Velemínská J. Skull shape asymmetry and the socioeconomic structure of an early medieval central European society. Am J Phys Anthropol. 2013;150(3):349-64.

20. Hartman C, Holton N, Miller S, Yokley T, Marshall S, Southard T. Nasal Septal Deviation and Facial Skeletal Asymmetries. Anat Rec (Hoboken). 2016;299(3):295-306.

21. Rusková H, Bejdová S, Peterka M, Krajíček V, Velemínská J. 3-D shape analysis of palatal surface in patients with unilateral complete cleft lip and palate. J Craniomaxillofac Surg. 2014;42(5):e140-7.

22. Schlager S, Rüdell A. Analysis of the human osseous nasal shape--population differences and sexual dimorphism. Am J Phys Anthropol. 2015;157(4):571-81.

23. Chovalopoulou ME, Papageorgopoulou C, Bertsatos A. Cranium asymmetry in a modern Greek population sample of known age and sex. Int J Legal Med. 2017;131(3):803-812.

24. Ibrová A, Dupej J, Stránská P, Velemínský P, Poláček L, Velemínská J. Facial skeleton asymmetry and its relationship to mastication in the Early Medieval period (Great Moravian Empire, Mikulčice, 9th-10th century). Arch Oral Biol. 2017;84:64-73.

25. Fuessinger MA, Schwarz S, Cornelius CP, Metzger MC, Ellis E 3rd, Probst F et al. Planning of skull reconstruction based on a statistical shape model combined with geometric morphometrics. Int J Comput Assist Radiol Surg. 2018;13(4):519-529.

26. Ceuninck K, Starbuck JM. A morphometric analysis of developmental instability in children born with unilateral cleft lip and palate. Clin Anat. 2019;32(2):206-211.

27. Ridel AF, Demeter F, Galland M, L'abbé EN, Vandermeulen D, Oettlé AC. Automatic landmarking as a convenient prerequisite for geometric morphometrics. Validation on cone beam computed tomography (CBCT)- based shape analysis of the nasal complex. Forensic Sci Int. 2020;306:95-105.

28. Jung $\mathrm{H}$, von Cramon-Taubadel $\mathrm{N}$. Comparison of cranial fluctuating asymmetry between normal and pathological specimens from a modern Thai skeletal group. Homo. 2018;69(4):188-97.

29. Espinosa S, Rabanal C, Toro-Ibacache V. Morphometric Characterization of Asymmetric Mandibles Due to Condylar Hyperactivity. J Oral Maxillofac Surg. 2019;77(5):1056-1067.

30. Weisensee KE, Spradley MK. Craniofacial asymmetry as a marker of socioeconomic status among undocumented Mexican immigrants in the United States. Econ Hum Biol. 2018;29:122-127.

31. Benazzi S, Senck S. Comparing 3-dimensional virtual methods for reconstruction in craniomaxillofacial surgery. J Oral Maxillofac Surg. 2011;69(4):1184-94.

32. Weisensee EK. Assessing the Relationship Between Fluctuating Asymmetry and Cause of Death in Skeletal Remains: A Test of the Developmental Origins of Health and Disease Hypothesis. Am J Hum Biol. 2013;25:411-17.

33. Katsube M, Rolfe SM, Bortolussi SR, Yamaguchi Y, Richman JM, Yamada $S$ et al. Analysis of facial skeletal asymmetry during foetal development using $\bigotimes \mathrm{CT}$ imaging. Orthod Craniofac Res. 2019;22 Suppl 1(Suppl 1):199-206.

34. Nur RB, Çakan DG, Arun T. Evaluation of facial hard and soft tissue asymmetry using cone-beam computed tomography. Am J Orthod Dentofacial Orthop. 2016;149(2):225-37.

35. Nikkhah D, Ponniah A, Ruff C, Dunaway D. Planning surgical reconstruction in Treacher-Collins syndrome using virtual simulation. Plast Reconstr Surg. 2013;132(5):790e-805e.

36. Ridel AF, Demeter F, Liebenberg J, L'Abbe' EN, Vandermeulen D, Oettlé AC. Skeletal dimensions as predictors for the shape of the nose in a South African sample: A cone-beam computed tomography (CBCT) study. Forensic Sci Int. 2018;289:18-26.

37. Senck S, Coquerelle M, Weber GW, Benazzi S. Virtual reconstruction of very large skull defects featuring partly and completely missing midsagittal planes. Anat Rec (Hoboken). 2013;296(5):745-58.

38. Ketoff S, Girinon F, Schlager S, Friess M, Schouman T, Rouch P et al. Zygomatic bone shape in intentional cranial deformations: a model for the study of the interactions between skull growth and facial morphology. J Anat. 2017;230(4):524-531.

39. Ahmad Y, Starbuck JM. Disruption of symmetry: A quantitative assessment of facial skeleton anatomy in children born with unilateral cleft lip and palate. Clin Anat. 2018;31(8):1129-1136

40. Fukase $\mathrm{H}$, Ito $\mathrm{T}$, Ishida $\mathrm{H}$. Geographic variation in nasal cavity form among three human groups from the Japanese Archipelago: Ecogeographic and functional implications. Am J Hum Biol. 2016;28(3):343-51

41. Wärmländer SKTS, Garvin H, Guyomarc'h P, Petaros A, Sholts SB. Landmark Typology in Applied Morphometrics Studies: What's the Point? Anat Rec (Hoboken). 2019;302(7):1144-1153.

42. O'Higgins P. Quantitative approaches to the study of craniofacial growth and evolution: Advances in morphometric techniques. In: O'Higgins P, Cohn M. Development, growth, and evolution: Implications for the study of the hominid skeleton. London, UK: Academic Press; 2000.

43. Ruskova H, Bejdová S, Peterka M, Krajiček V, Veleminska J. 3-D shape analysis of palatal surface in patients with unilateral complete cleft lip and palate. J Craniomaxillofac Surg. 2014;42(5):e140-7. 